\title{
PENGARUH PENYULUHAN KESEHATAN TENTANG PENANGANAN TERSEDAK TERHADAP PENGETAHUAN IBU MENYUSUI
}

\author{
Juliana Sisca Pandegirot \\ Jimmy Posangi \\ Gresty N. M. Masi
}

\author{
Program Studi Ilmu Keperawatan Fakultas Kedokteran \\ Universitas Sam Ratulangi \\ Email : siskacikapandegirot@gmail.com
}

\begin{abstract}
Choking is a blockage of the airway due to foreign objects in total or in part, causing the victim to have difficulty breathing and lack of oxygen, it can even cause death immediately. In Indonesia, according to data obtained from RSUD Dr.Harjono Ponorogo, Semarang, in 2009 there were 157 cases of chocking. Research Objectives: The purpose of this study was to determine the effect of health education on choking handling on breastfeeding mothers in Puskesmas Ranotana Weru. Research Methods: The research method is Pre-Experiment with one group pre-test post-test research design. A sample of 16 breastfeeding mothers. Research Results: using the Wilcoxon statistical test, obtained p-value $=0,000(<0.05)$. Conclusion: There have impact of health education on the choking treatment of the knowledge of breastfeeding mother in Puskesmas Ranotana Weru.
\end{abstract} Keywords : Health Counseling, handling choking on knowledge

Abstrak : Tersedak adalah tersumbatnya saluran napas akibat benda asing secara total atau sebagian, sehingga menyebabkan korban sulit bernapas dan kekurangan oksigen, bahkan dapat segera menimbulkan kematian. Di indonesia menurut data yang diperoleh dari RSUD dr Harjono Ponorogo Kota Semarang tahun 2009 ditemukan kasus tersedak sebanyak 157. Tujuan Penelitian : Tujuan dalam Penelitian ini adalah untuk Mengetahui Pengaruh Penyuluhan Kesehatan Tentang Penanganan Tersedak Terhadap Pengetahuan Ibu Menyusui di Puskesmas Ranotana Weru. Metode Penelitian : Metode dalam Penelitian adalah Preexperimen dengan rancangan penelitian one group pre test post tes. Sampel sebanyak $16 \mathrm{ibu}-$ ibu menyusui. Hasil Penelitian : menggunakan uji statistik Wilcoxon, didapatkan nilai pvalue $=0,000 \quad(<0,05)$. Kesimpulan: Ada pengaruh penyuluhan kesehatan tentang penanganan tersedak terhadap pengetahuan ibu menyusui di puskesmas ranotana weru. Kata Kunci : Penyuluhan Kesehatahan, penanganan tersedak

\section{PENDAHULUAN}

Tersedak adalah tersumbatnya saluran napas akibat benda asing secara total atau sebagian, sehingga menyebabkan korban sulit bernapas dan kekurangan oksigen, bahkan dapat segera menimbulkan kematian (Bagian Diklat RSCM, 2015). Berdasarkan Survey Demografi dan Kesehatan Indonesia, Angka Kematian Bayi di Indonesia sebesar 34 per 1.000 kelahiran hidup, berarti sama halnya dengan sebanyak 157.000 bayi meninggal pertahun atau setiap hari 430 bayi meninggal. Penemuan data oleh Centers of Diases Control and Provention sebanyak 34 anak di bawah ke IGD setiap hari akibat tersedak. Sebanyak 57 anak meninggal setiap tahun karena tidak mendapatkan pertolongan yang memadai saat tersedak.

Angka Kematian Bayi di Indonesia sebesar 34 per 1.000 kelahiran hidup, berarti sama halnya dengan sebanyak 157.000 bayi meninggal pertahun atau setiap hari 430 bayi meninggal. Penyebab kematian bayi sebesar $10 \%$ adalah karena masalah pemberian ASI (Depkes RI, 2009). Menurut data, angka kematian yang disebabkan oleh obstruksi jalan napas khususnya tersedak masih tinggi di 
kalangan bayi (Utami, 2014). Menurut World Health Organization (WHO) sekitar 17.537 anak-anak berusia 3 tahun atau lebih muda sangat rentan tersedak, 59,5\% berhubungan dengan makanan, 31,4\% tersedak karena benda asing, dan $9.1 \%$ penyebabnya tidak diketahui.

Data yang diperoleh dari RSUD dr Harjono Ponorogo Kota Semarang tahun 2009 ditemukan kasus tersedak sebanyak 157. Dan pada tahun 2010 telah mengalami penurunan menjadi 112 orang (Chlivisia, C.P., et all 2015). Survey data awal yang dilakukan di Puskesmas Ranotana, diketahui bayi yang berumur 0-6 bulan ada 255 bayi, dan yang mendapatkan ASI Ekslusif sampai pada bulan Agustus ada 62 bayi. Peneliti melakukan wawancara dengan 6 ibu yang ada untuk menanyakan keadaan anak mereka saat menyusu. Setelah dilakukan wawancara didapatkan 3 anak yang pernah tersedak saat menyusui dan penanganan tersedak tidak diketahui oleh mereka karena kurangnya edukasi.

Penelitian yang dilakukan oleh Sumarningsih, D. 2015 tentang pengaruh edukasi keluarga tentang pencegahan dan penanganan tersedak pada anak terhadap pengetahuan dan keterampilan keluarga di Dusun Ngebel RT 9 Tamantirto Kasihan Bantul diperoleh data pengetahuan keluarga tentang pencegahan dan penanganan tersedak pada anak sebelum dilakukan edukasi sebanyak 19 orang (95\%) mempunyai pengetahuan kurang dan 1 orang $(5 \%)$ mempunyai pengetahuan cukup. Sedangkan setelah diberikan edukasi sebanyak 20 orang (100\%) dalam kategori baik.

Pengalaman ibu dalam pemberian ASI dipengaruhi oleh faktor pekerjaan, pengetahuan, dan budaya (Lina, S 2015). Pengetahuan ibu yang kurang baik tentang teknik yang tepat dalam pemberian ASI dapat beresiko dan menyebabkan tersedak pada bayi, sedangkan pengetahuan ibu yang baik tentang teknik yang tepat dalam pemberian ASI mampu mengurangi resiko pada bayi dan mencegah terjadinya kejadian tersedak. Demikian juga Posisi menyusui yang tidak tepat akan menyebabkan tersedak, dengan posisi yang benar pada saat ASI yang memancar (penuh), bayi ditengkurapkan di atas dada ibu, tangan ibu sedikit menahan kepala bayi maka bayi tidak akan tersedak (Lina,S. 2015).

Pentingnya penyuluhan tentang penanganan tersedak sangat diperlukan untuk mencegah terjadinya tersedak. Informasi edukasi dibutuhkan untuk penanganan yang cepat dan tepat. Sehingga masyarakat tidak hanya sadar, tahu, dan mengerti tetapi juga mau dan bisa melakukan satu anjuran yang ada hubungan dengan kesehatan yaitu tentang pencegahan dan pelaksanaan tersedak pada anak sehingga akan meningkatkan pengetahuan dan ketrampilan keluarga dalam melakukannya (Surmaningsih, D, 2015).

\section{METODE PENELITIAN}

Metode yang digunakan dalam penelitian ini adalah metode one group pre test post test yaitu rancangan yang tidak ada kelompok pembanding (kontrol) tapi paling tidak sudah dilakukan observasi pertama (pre test) yang memungkinkan peneliti dapat menguji perubahan yang terjadi setelah adanya eksperimen (perlakuan) (Notoatmodjo, 2012). Populasi dalam penelitian ini ialah seluruh ibu-ibu menyusui di Puskesmas Ranotana Weru. Teknik sampling yang digunakan dalam penelitian adalah perhitungan sampel untuk penelitian eksperimental secara sederhana untuk mengantisipasi hilangnya unit eksperimen dilakukan koreksi dengan 1/(1-f), dimana $f$ adalah proporsi unit ekserimen yang hilang atau mengundurkan diri atau drop out. Maka diambil sampel untuk penelitian ini yaitu 15 ditambahkan dengan hasil drop out 1, jadi sampel penelitian berjumlah 16 (responden).

Instrumen penelitian yang akan digunakan dalam penelitian ini yaitu instrumen kusioner penanganan tersedak. Kuesioner ini merupakan instrumen yang akan mengetahui tentang pengetahuan penanganan tersedak. Kuesioner ini dibuat 
sendiri oleh peneliti dan sudah diuji validitas dan reliabilitas. Untuk mengetahui validitas kuesioner dilakukan dengan membandingkan nilai $r$ table dengan nilai $r$ hitung. Rumus : $\mathrm{df}=\mathrm{N}-2=$ $20-2=18$ pada tingkat kemaknaan $5 \%$, didapat nilai $\mathrm{r}$ tabel $=0.443$. Nilai $\mathrm{r}$ table dilihat dengan menggunakan tabel $\mathrm{r}$ yaitu $=$ 0,443. Jadi dinyatakan valid karena $r$ hitung > $\mathrm{r}$ tabel. Masing-masing pertanyaan/variabel dibandingkan nilai $r$ hitungdengan $r$ table dengan ketentuan bila $\mathrm{r}$ hitung $>\mathrm{r}$ tabel, maka pertanyaan tersebut valid.

Kuesioner yang digunakan pada penelitian ini menggunakan jenis bentuk pertanyaan Multiple Choice yaitu memilih jawaban paling tepat yang pertanyaannya diberi skor masing-masing sesuai dengan sistem penilaian yang telah ditetapkan yakni 2 = untuk jawaban yang paling benar $1=$ untuk jawaban yang mendekati benar dan $0=$ untuk jawaban yang salah. Dari 10 pertanyaan tentang tingkat pegetahuan yang diuji, terlihat bahwa $r$ hitung $>r$ tabel. Ini menunjukan bahwa untuk pertanyaan tingkat pengetahuan tersebut valid dan dapat dijadikan sebagai alat ukur dalam penelitian ini. Apabila total jawaban responden $0-6,6$ maka dikategorikan pengetahuan kurang baik, apabila total jawaban 6,7 - 13,2 maka dikategorikan pengetahuan cukup baik, dan apabila total jawaban berada di atas 13,3 maka dikategorikan pengetahuan baik.

\section{HASIL dan PEMBAHASAN}

1. Karakteristik Responden

Tabel 1. Distribusi Frekuensi berdasarkan usia responden

\begin{tabular}{lcc}
\hline Usia & $\mathbf{n}$ & $\mathbf{\%}$ \\
\hline$<20$ Tahun & 3 & 18,8 \\
20-30 Tahun & 11 & 68,8 \\
$>30$ Tahun & 2 & 12,5 \\
\hline Total & $\mathbf{1 6}$ & $\mathbf{1 0 0}$ \\
\hline
\end{tabular}

Tabel 1 menunjukkan bahwa karakteristik responden menurut usia sebagian besar responden pada rentang usia 20-30 tahun yaitu 11 orang $(68,8 \%)$ dan yang paling sedikit responden yaitu usia > 30 tahun yaitu 2 orang $(12,5 \%)$.

Tabel 2. Distribusi Frekuensi berdasarkan pekerjaan responden

\begin{tabular}{ccc}
\hline Pekerjaan & n & \% \\
\hline IRT & 15 & 93,8 \\
Guru Honorer & 1 & 6,3 \\
\hline Total & $\mathbf{1 6}$ & $\mathbf{1 0 0}$ \\
\hline
\end{tabular}

Tabel 2 berdasarkan karakteristik responden menurut pekerjaan sebagian besar responden bekerja sebagai IRT 15 orang $(93,8 \%)$ dan yang paling sedikit responden bekerja sebagai guru honorer yaitu 1 orang $(6,3 \%)$.

Tabel 3. Distribusi Frekuensi berdasarkan pendidikan responden

\begin{tabular}{lcc}
\hline Pendidikan & n & \% \\
\hline SD & 1 & 6,3 \\
SMK & 5 & 31,3 \\
SMA & 8 & 50,0 \\
S1 & 2 & 12,5 \\
\hline Total & $\mathbf{1 6}$ & $\mathbf{1 0 0}$ \\
\hline
\end{tabular}

Tabel 3 pendidikan terakhir yang paling banyak yaitu di bangku SMA 8 orang $(50,0 \%)$, dan paling sedikit berpendidikan terakhir di bangku SD 1 orang $(6,3 \%)$.

\section{Analisa Univariat}

Tabel 4. Distribusi Tingkat Pengetahuan Responden Pre Test-Post Test

\begin{tabular}{llll}
\hline Variabel & Mean & SD & Min-Max \\
\hline Pre Test & 9,75 & 1,844 & $6-21$ \\
Post Test & 17,56 & 1,861 & $14-20$ \\
\hline
\end{tabular}

Data pada tabel 4 menunjukkan bahwa pre test tingkat pengetahuan dari responden yaitu 9,75 dengan standar deviasi 1844, sedangkan post test tingkat pengetahuan dari responden rata-ratanya lebih tinggi yaitu 17,56 dengan standar deviasi 1,861. 
Tabel 5. Distribusi Kriteria Pengetahuan Pre Test-Post Test

\begin{tabular}{lcccc}
\hline $\begin{array}{l}\text { Tingkat } \\
\text { Pengetahuan }\end{array}$ & \multicolumn{2}{l}{ Pre Test } & \multicolumn{2}{c}{ Post Test } \\
\hline Kurang & $\mathrm{n}$ & $\%$ & $\mathrm{n}$ & $\%$ \\
Cukup & 1 & 6,3 & 0 & 0 \\
Baik & 15 & 93,8 & 0 & 0 \\
Total & 0 & 0 & 16 & 100 \\
& $\mathbf{1 6}$ & $\mathbf{1 0 0}$ & $\mathbf{1 6}$ & $\mathbf{1 0 0}$ \\
\hline
\end{tabular}

Tabel 6. Analisis Pre Test-Post Test Tingkat Pengetahuan

\begin{tabular}{lllll}
\hline Variabel & Mean & SD & Z & p-value \\
\hline Pre Test & 9.75 & 1,844 & $-3,542$ & 0,000 \\
Post Test & 17,56 & 1,861 & & \\
\hline
\end{tabular}

Hasil uji Wilcoxon pada tabel 6 terdapat pengaruh pemberian penyuluhan kesehatan dilihat dari nilai meannya dan nilai $\mathrm{p}$-value $0,000(<0,05)$. Dengan demikian dapat disimpulkan bahwa ada pengaruh pemberian penyuluhan kesehatan terhadap tingkat pengetahuan responden.

\section{Pembahasan}

\section{Usia}

Penelitian ini dilakukan di Puskesmas Ranotana Weru Kecamatan Wanea Kota Manado pada 16 ibu-ibu menyusui yang menjadi responden. Dari 16 sampel yang diteliti diperoleh presentase usia responden terbanyak pada rentang umur 20-30 tahun yaitu 11 orang $(68,8 \%)$ dan yang paling sedikit responden yaitu usia > 30 tahun yaitu 2 orang (12,5\%). Hasil penelitian ini sejalan dengan penelitian yang dilakukan oleh Lina (2015) tentang Gambaran pengetahuan ibu dalam Penanganan tersedak ASI pada bayi, menyatakan bahwa mayoritas responden mempunyai usia 26-35 sebanyak 18 responden $(69,2 \%)$, hal ini dikarenakan usia tersebut merupakan usia yang produktif dan dapat dengan mudah memperoleh pengetahuan dan memperluas pengalaman.

\section{Pekerjaan}

Presentase yang diperoleh dari 16 sampel sebagian besar responden bekerja sebagai IRT 15 orang $(93,8 \%)$ dan yang paling sedikit responden bekerja sebagai guru honorer yaitu 1 orang $(6,3 \%)$. Penelitian yang dilakukan oleh Citra (2016) tentang gambaran tingkat pengetahuan ibu hamil trimester III tentang manfaat pemberian asi eksklusif pada bayi menunjukkan hasil 52,6\% adalah ibu rumah tangga. Sebagai ibu rumah tangga maka akan lebih memiliki banyak waktu kosong dibandingkan dengan ibu yang bekerja, sehingga ibu dapat selalu aktif pada kehadiran penyuluhan kesehatan tentang ASI eksklusif yang diadakan oleh tenaga kesehatan setempat.

\section{Pendidikan}

Responden yang diteliti sebanyak 16 sampel sebagian besar berpendidikan terakhir di bangku SMA 8 orang $(50,0 \%)$. Hasil penelitian ini sesuai dengan penelitian yang dilakukan oleh Vera (2016) tentang pengaruh pendidikan kesehatan tentang penanganan tersedak benda asing pada balita terhadap self efficiacy ibu menunjukkan hasil 25 atau $50 \%$ responden berpendidikan terakhir SMA yang artinya dimana mayoritas tingkat pendidikan responden sudah tinggi dimana tingkat yang lebih tinggi mempengaruhi persepsi seseorang untuk mengambil keputusan dan bertindak. Notoadmojo (2014).

4.Tingkat pengetahuan sebelum dan sesudah diberikan penyuluhan kesehatan tentang penangan tersedak

Pengetahuan responden tentang penanganan tersedak sebelum diberikan penyuluhan kesehatan sebagian besar adalah cukup 93,8\%. Pengetahuan yang dimiliki responden sesuai dengan wawancara dan setelah dilakukan penelitian yaitu mereka memiliki pengetahuan penanganan tersedak berdasarkan informasi oleh orang tua maupun tetangga, informasi diinternet, dan kejadian yang pernah dialami oleh anak mereka sendiri. Hubungan informasi dan pengalaman terhadap pengetahuan sebagaimana dikemukakan oleh Notoatmodjo (2010) bahwa, salah satu 
faktor yang mempengaruhi pengetahuan adalah pengalaman.

Berdasarkan data didapatkan hasil kurang (6,3\%), kurangnya informasi yang didapatkan atau pengalaman bisa mempengaruhi pengetahuan seseorang dalam menangani apapun keadaan yang terjadi. Tingkat pengetahuan penanangan tersedak sebelum dilakukan penyuluhan kesehatan sebagian besar adalah cukup, salah satu faktor penyebab yang berhubungan dengan tingkat pengetahuan antara lain informasi tentang penanganan tersedak kurang diketahui. Sehingga saat pengisian kuesioner jawaban yang diisi kurang tepat.

Pengetahuan ibu-ibu menyusui setelah diberikan penyuluhan adalah baik yaitu $16(100 \%)$. Hasil data tersebut setelah dilakukan perlakuan dengan adanya penyuluhan kesehatan memiliki pengetahuan baik, hal ini menunjukan bahwa terdapat peningkatan yang signifikan terhadap pengetahuan ibu-ibu menyusui. Dengan adanya Leaflet atau penyampaian informasi kesehatan dalam bentuk kalimat, gambar, membuat responden semakin memahami isi penyuluhan dan penanganan tersedak karena disertai gambar. Menurut teori yang dikemukakan oleh Notoatmodjo (2010) bahwa pengetahuan adalah hasil tahu dan terjadi setelah seseorang melakukan penginderaan terhadap suatu objek tertentu. Penginderaan terjadi melalui pancaindra manusia, yaitu indra penglihatan, pendengaran, penciuman, rasa dan raba. Sebagian besar pengetahuan diperoleh melalui mata dan telinga. Salah satu faktor juga yang dapat memengaruhi pengetahuan seseorang yaitu pendidikan.

5.Pengaruh penyuluhan kesehatan terhadap tingkat pengetahuan tentang penanganan tersedak

Hasil analisa data yang dilakukan dengan uji statistic Wilcoxon (Signed Rank Test) didapatkan tingkat signifikan $\alpha=$ 0,000 . Karena nilai signifikan $\alpha=0,000<$ dari taraf nyata yaitu 0,05, maka Ho ditolak. Penelitian ini menunjukan bahwa rata-rata tingkat pengetahuan sebelum diberikan penyuluhan kesehatan adalah 9,75, kemudian meningkat menjadi 17,56 setelah diberikan penyuluhan kesehatan. Dapat disimpulkan bahwa ada pengaruh yang signifikan pemberian penyuluhan kesehatan terhadap tingkat pengetahuan responden, maka Ha diterima. Penelitian yang telah dilakukan di Puskesmas ranotana Weru yaitu dengan menggunakan kusioner. Pemberian kusioner dilakukan sebelum dan sesudah penyuluhan kesehatan. Waktu yang dipakai selama mengisi kusioner yaitu selama 7-10 menit. Setelah kuisioner terisi maka langkah selanjutnya dilakukan penyuluhan kesehatan.

Penyuluhan yang diberikan selain penjelasan dan bagaimana cara menanganai tersedak, peneliti juga memberikan alat peraga berupa leaflet yang membantu responden untuk lebih mudah memahami isi dari penyuluhan karena isi dari leaflet diberikan gambargambar tentang penangganan tersedak. Penyuluhan tidak lepas dari media karena melalui media, pesan disampaikan dengan mudah untuk dipahami. Media dapat menghindari kesalahan persepsi, memperjelas informasi, dan mempermudah pengertian. Dengan demikian, sasaran dapat mempelajari dan mengadopsi pesanpesan yang disampaikan. Notoadmojo (2007). Setalah diberikan penyuluhan, responden diberikan lagi kuisioner untuk melihat bagaimana pengaruh atau perubahan setelah mendapat penyuluhan kesehatan. Dari hasil yang ada terdapat pengaruh penyuluhan kesehatan tentang pengetahuan penanganan tersedak. Dengan adanya penyuluhan membuat responden menjadi tahu, memahami dan diharapkan bisa menerapkan setiap informasi yang telah diketahui. Pengetahuan akan terus bertambah jika kita terus mencari informasi dan sering mendapat penyuluhan kesehatan.

Penelitian ini juga didukung oleh Sumarningsih (2015) dengan judul 
Pengaruh Edukasi Keluarga Tentang Pencegahan Dan Penanganan Tersedak Pada Anak terhadap Pengetahuan dan Keterampilan Keluarga dimana terdapat pengaruh edukasi keluarga terhadap tingkat pengetahuan tentang pencegahan dan penanganan tersedak. Hal ini dipengaruhi oleh adanya pemberian edukasi yang meningkatkan pengetahuan responden. Dengan adanya penyuluhan kesehatan tentang penanganan tersedak membuat responden menjadi tahu dan telah menambah peningkatan pengetahuan. Hal ini sesuai dengan teori yang dikemukakan oleh Notoatmodjo (2012) bahwa pendidikan kesehatan dapat mengubah pengetahuan seseorang atau masyarakat dalam pengambilan tindakan yang berhubungan dengan kesehatan.

\section{SIMPULAN}

Hasil kesimpulan dari pembahasan mengenai pengaruh penyuluhan kesehatan tentang penanganan tersedak terhadap pengetahuan ibu menyusui di puskesmas ranotana weu didapati Tingkat pengetahuan ibu-ibu menyusui pada pre test sebagian besar responden memiliki pengetahuan dalam kategori yang cukup, sedangkan pada post test sebagian besar responden memiliki pengetahuan dalam kategori yang baik. Dan terdapat pengaruh penyuluhan kesehatan tentang penanganan tersedak terhadap pengetahuan ibu menyusui di puskesmas ranotana weru.

\section{DAFTAR PUSTAKA}

Bagian Diklat RSCM. (2015).Tersedak. Pelatihan Internal RSCM Bantuan Hidup Dasar 2015. Hal 8

Citra, (2016) Gambaran Tingkat Pengetahuan Ibu Hamil Trimester III Tentang Manfaat Pemberian ASI Eksklusif Pada Bayi. Skripsi Hal 72

Chlivisia, C.P., et all (2015) Hubungan Tingkat Pengetahuan Dengan Perilaku Ibu Tentang Pertolongan Pertama Pada Anak Tersedak Di
Posyandu Dusun Saden Sawahan Ngemplak Boyolali. Skripsi Hal 2

Depkes RI, 2009. Materi Penyuluhan Inisiasi Menyusui Dini (IMD). Jakarta. Hal 2

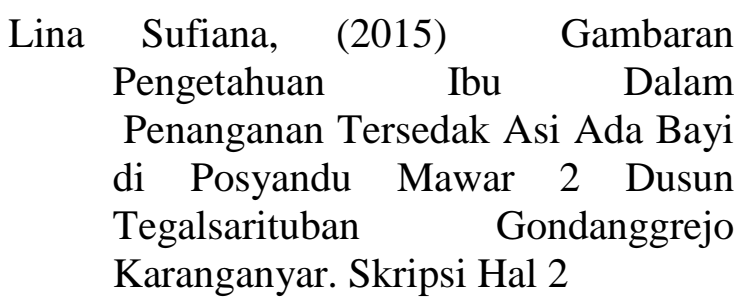

Notoadmojo, S. 2010. Promosi Kesehatan dan Ilmu Prilaku. Jakarta: Rineka Cipta. Hal 47

Notoadmojo, S. 2012 Metodologi Penelitian Kesehatan. Jakarta. Rineka Cipta. Hal 95

Notoadmojo S. 2014. Metodologi Penelitian Kesehatan. Jakarta : PT. Rineka Cipta. Hal 64

Sumarnngsih, D. (2015). Pengaruh Edukasi Keluarga Tentang Pencegahan Dan Penanganan Tersedak Pada Anak Terhadap Pengetahuan Dan Ketrampilan Keluarga Dukuh Ngebel RT 09 Tamantirto Kasihan Bantul. Skripsi Hal 9

Utami, D.S (2014) Teknik mencegah bayi tersedak pada ibu menyusui di puskesmas Desa Demang Kecamatan Besuki Situbondo. Skripsi Hal 3

Vera (2016) Pengaruh Pendidikan Kesehatan Tentang Penanganan Tersedak Benda Asing Pada Balita Terhadap Self Efficiacy Ibu Di Posyandu Desa Palem Karangrejo Magetan. Skripsi Hal 5 